\title{
Eroding Entitlements as Litigation Commitment
}

\author{
Ian Ayres $\dagger$
}

This Comment on Omri Ben-Shahar's excellent article makes two points:

1. Entitlements might be more valuable under an erosion rule than under a no-erosion rule.

2. In contractual settings, any observed irrelevance is likely to be the product of forces that are independent of Omri BenShahar's "litigation commitment" antierosion effect.

But before discussing these two issues, let me briefly reformulate Ben-Shahar's contribution. ${ }^{1}$ First, erosion rules can give rise to an "antierosion" effect because erosion rules are a litigation commitment device that helps entitlement holders commit to prosecuting a broader class of opportunistic breaches. In BenShahar's model, erosion is caused by promisors who intentionally chisel on their duties, knowing, because of the costs of litigation, that the promisees cannot credibly threaten to sue.

Second, Ben-Shahar's irrelevance claim is both stronger and weaker than he acknowledges. The irrelevance claim is stronger, because his model shows not just that erosion costs will be the same under different erosion rules, but that we know that these costs will always be exactly equal to litigation costs saved. The promisors will always chisel to the point where the promisee is almost indifferent between paying litigation costs and swallowing the erosion costs.

The irrelevance claim is weaker than Ben-Shahar suggests because, while total erosion costs stay the same, different erosion rules produce different profiles (or cash flows) of erosion. The model predicts that no-erosion rules will produce constant amounts of erosion in each period, but that erosion rules will produce increasing amounts of erosion in each period (less erosion than under a no-erosion rule in early periods and more erosion than under a no-erosion rule in later periods). These different erosion profiles predicted by the model provide an important

\footnotetext{
$\dagger$ William K. Townsend Professor of Law, Yale Law School. ian.ayres@yale.edu.

1 Omri Ben-Shahar, The Tentative Case Against Flexibility in Commercial Law, 66 U Chi L Rev 781 (1999).
} 
testable implication. If we don't think that promisors increase their chiseling through the course of their performance, then we might question whether other parts of Ben-Shahar's model are accurate.

\section{ERosion RULes Might MAKE Entitlement MoRE VALUABLE}

Ben-Shahar is so focused on his irrelevance conjecture ${ }^{2}$ that he fails to see that there are two ways in which irrelevance might fail. Most of the examples in his final section suggest circumstances where erosion costs would be higher under an erosion rule than under a no-erosion rule; but to my mind a more important possibility-and really the take-home lesson of his fine article-is that erosion costs might be lower under an erosion rule than under a no-erosion rule. Or, put slightly differently, an entitlement might be more valuable under an erosion rule than under a no-erosion rule. Appreciating the litigation commitment effect of exosion rules raises the perverse possibility that rightholders might value a potentially eroding entitlement more than a noneroding entitlement.

Consider the following trademark example. Assume that each suit for infringement will cost Coke 10 , and that we parameterize the degree of infringement so that the direct cost of infringement of size $\mathrm{X}$ is $\$ \mathrm{X}$. Assume that the demand for infringement (if infringers do not expect enforcement) is such that one person would choose $X=8$ each period, and one person would choose $\mathrm{X}=15$. Under a no-erosion regime, Coke would let the small infinger $(X=8)$ infringe each period but credibly threaten to sue (and thereby deter) the potential large $(X=15)$ infringer. Under an erosion regime, however, Coke could credibly threaten to sue even the small infringer. If Coke failed to sue the small infringer under an erosion rule, in subsequent periods Coke would not be able to sue credibly the large potential infringer. In equilibrium under an erosion rule, Coke would not need to spend any money enforcing its rights, because infringers would know that Coke has strong incentives to go after small infringers. The litigation commitment effect (what Ben-Shahar calls the antierosion or rigidity effect) is so strong that Coke's expected erosion costs (including costs of enforcement) drop from $\$ 8$ per period to $\$ 0$. Coke perversely prefers the potentially eroding character of trade-

\footnotetext{
2 The Article is a little at war with itself on this issue, arguing on the one hand that the flexibility effect and the rigidity effect "generally balance out," id at 796, and, on the other, that "the irrelevance claim is false," id at 818 .
} 
marks. ${ }^{3}$ An analogous story might be told about the UCC. BenShahar rightfully emphasizes the possibility that past course of dealing and usage of trade might trump the express terms of a subsequent contract. "If the rightholder acquiesced to violations of her explicit right throughout her past dealings with the violator (or, potentially, with others), she might lose the power to enforce this right even though she explicitly asserted it anew in the most recent contract." " One might imagine a monopolist who is trying to stop an individual buyer from paying late. Under the expansive course of dealing/usage of trade rule, the monopolist might find it more credible to threaten suit against small chiselers, arguing "If I don't sue you, I lose my ability to deter a large class of more substantial chiseling."

To my mind, the possibility that rights could be more valuable under an erosion rule is at least as important as the irrelevance result. Even if neither is true (meaning that rights are less valuable under an erosion rule), the litigation commitment effect that Ben-Shahar has identified suggests that erosion rules will not erode the value of rights nearly as much as we previously, naively might have thought.

\section{OTHER IRRELEVANCE-INDUCING FACTORS}

While Ben-Shahar is careful to discuss a host of factors that could cause his irrelevance benchmark to fail, he does not spend as much time analyzing whether irrelevance might be induced by other factors-independent of the litigation commitment effect. Particularly in contractual settings, the possibilities of ex ante adjustments and ex post objection or reprisal may induce irrelevance (that is, cause the legal erosion rules not to affect the amount of equilibrium erosion). When the person who owes the duty is in privity with the rightholder, the litigation commitment effect may be less important than in settings-like the foregoing trademark example-where the possibility of adjusting ex ante terms and refusing ex post to contract further is not as salient.

\section{A. Objection}

The UCC has made it difficult for parties to opt out of an erosion rule through ex ante contracting. Provisions requiring that all waivers or modifications must be in writing are at times not

3 This example critically assumes that Coke can costlessly detect small and large infringement. Erosion rules are less likely to be attractive to rightholders with high monitoring costs.

- Id at 791. 
enforced (and courts find that these antiwaiver provisions can themselves be waived by nonwritten conduct). ${ }^{5}$ But the UCC allows promisees to unilaterally opt out of erosion ex post by objecting to a breach. ${ }^{6}$ Ben-Shahar acknowledges the importance of objection in the last part of the article, ${ }^{7}$ but his models exclude the possibility of promisee objection.

When a promisor chisels, erosion rules give the promisee three choices: sue, object, or acquiesce. Even when suing is prohibitively expensive, a promisee may be able to object in a timely manner (at a much lower cost) and thereby eliminate any prospective eroding effect on the promisor's prospective duties. There would be a broad range of breaches where it might not be credible to sue but where it might be credible to object.

If we explicitly add an objection option to Ben-Shahar's basic model, then a regime of potential erosion tends to come even closer to replicating a no-erosion equilibrium. When objection costs are substantially lower than litigation costs, promisors will chisel the same amount each period, as though they were performing under a no-erosion rule. ${ }^{8}$ Adding an objection model produces an equilibrium that is arguably closer to reality in that chiseling does not seem to increase over the life of a contract. However, the objection option model predicts that we will routinely see promisees object in order to opt out of prospective erosion and, as Ben-Shahar notes, we do not see many objections in equilibrium.

\section{B. Adjust Initial Terms}

\footnotetext{
5 See UCC $\$ 2-208(3)$ (ALI 1996) ("such course of performance shall be relevant to show waiver or modification of any term inconsistent with such course of performance"); James J. White and Robert S. Summers, 1 Uniform Commercial Code $\$ 1-6$ at 38 (West 4th ed 1995) ('[I]f, in light of a 'relevant' course of performance, either a waiver or a modification (so defined) is thus shown, courts sometimes say that course of performance 'controls' and thus alters the express terms.").

- UCC § 2-208(1) ("any course of performance accepted or acquiesced in without objection shall be relevant to determine the meaning of the agreement"). Objection can also restrict the possibility that even course of dealing can trump express terms of a subsequent agreement. As a descriptive matter, I would predict that courts would not allow course of performance or usage of trade to trump subsequent express terms if the subsequent express terms expressly object to (or distinguish themselves from) the prior practice-à la "notwithstanding prior practices of accepting late delivery, we intend late delivery in this contract to constitute an actionable breach." Ben-Shahar makes the memorable assertion that "parties have limited power to opt out of the 'jurisidiction' of their own past practice." Ben-Shahar, $66 \mathrm{U}$ Chi L Rev at 792 (cited in note 1). But I wonder whether this is an accurate description, given the possibility of inserting the foregoing "notwithstanding" clause.

7 Ben-Shahar, $66 \mathrm{U}$ Chi L Rev at 807-08 (cited in note 1).

- For example, if the cost of enforcement (litigation) is 10 and the cost of objecting is 1 , then the cost of an erosion rule will again be 10 per period. The promisor will chisel 9 and the promisee will object to make sure that her future rights do not erode.
} 
Another reason that erosion rules may be irrelevant--even if contractual rights potentially erode-is that parties can often adjust the terms of the initial agreement to correct for expected ex post chiseling. When a host knows that a dinner guest habitually comes an hour late, it is common to invite the guest to come an hour earlier. Analogously, in Ben-Shahar's model, the promisee and promisor, foreseeing the ex post chiseling effect of delayed payment, can restructure the initial agreement to take into account the future equilibrium chiseling and thereby ensure that the promisor will pay on the desired day. Even if different erosion rules give rise to different equilibrium erosion profiles, as long as these profiles are foreseeable ex ante, adjustment can neutralize any erosion effect. This is similar to the idea that inflation will be neutral with regard to substantive economic behavior as long as it is foreseeable, because parties will be able to adjust the nominal terms of their contracts so as to keep the real terms unaffected.

\section{Reprisals}

Finally and perhaps most importantly, the possibility of reprisals may independently deter promisees from chiseling under either an erosion or no-erosion rule. Ben-Shahar's model assumes that the buyer has the only opportunity to chisel. This assumption is a bit odd in an article that so eloquently focuses on the course of performance, course of dealing, and usage of trade. Analyzing a true course of performance and dealing would indicate that the promisee/seller might react to late payment by chiseling on its own prospective duties-by delivering late or by delivering products of slightly inferior quality. A promisee may not credibly threaten to sue because of prohibitive information costs, but it is difficult to see why the promisee could not credibly threaten to chisel itself. Moreover, a promisor's late payments may make other sellers less likely to contract with him in the future. Opportunistic chiseling-particularly of the accelerating kind that Ben-Shahar predicts under erosion rules-may be an unprofitable strategy once promisors take into account the threat of reprisals by this and other sellers.

\section{EROSION VERSUS FLEXIBIIITY}

There is an important slippage between the concepts of "erosion" and "flexibility." When Karl Llewellyn spoke of trying to engender more flexibility in commercial contracting, I take it to mean that he wanted to facilitate good faith modification for 
changed circumstances. Ben-Shahar's model, however, doesn't admit changed circumstances; consequently, the parties never have a need to modify their obligations ex post. Instead, all ex post modifications are erosions caused by what might fairly be described as opportunistic chiseling. Even though Ben-Shahar concludes that erosion rules might-contrary to Llewellyn's vision-make contractual performance more rigid, his model cannot tell us how erosion rules will affect parties' willingness to agree to good faith modifications for changed circumstances. To answer this latter question, we would need a richer model that admitted both good faith and bad faith attempted modifications. In this richer model, we would need to predict promisees' willingness to agree to both one-time and persistent modification (via the dual routes of objection and acquiescence).

When should the law allow a promisee who has acquiesced (that is, not objected and not sued) to past breaches to prevail in a current suit for breach of contract? This is obviously the $\$ 64,000$ question. I think a lot turns on one's theory of what is causing the current litigation. Under one theory, the plaintiff's suit is itself opportunistic or pretextual-in that the promisee who wasn't bothered by nonperformance in the past seizes on the nonperformance now to extract supercompensatory damages or settlement. Under another theory, however, the promisee may be able to observe additional information that it cannot prove to the court; it thus has a legitimate (but unprovable) basis for having acquiesced in the past but suing in the present. When certain information is nonverifiable (and therefore noncontractable), parties may strongly prefer to give the promisee an option to sue for even trivial breaches to which it has acquiesced in the past. Erosion rules can make it more difficult for parties to mitigate contractability problems.

If we believe that most post-acquiescence suits are pretextual (and I bet that Llewellyn implicitly entertained such a belief), then we will be drawn to erosion rules that place a duty of objecting on the promisee. If, however, we believe that most post-acquiescence suits are driven by legitimate private information that cannot be proven to a court (but that was nonetheless observed by the promisee), then we will be drawn toward no-erosion rules that place the duty of more express modification on the promisor. ${ }^{9}$

- This is undoubtedly not the whole story. To the extent that the legal erosion rule is merely a default, one would need to analyze the usual host of transaction cost and information variables to help predict the rule that produces the more efficient equilibria. See Ian Ayres and Robert Gertner, Majoritarian v. Minoritarian Defaults, 51 Stan I Rev 1591 (forthcoming 1999). 